\title{
Betulinic acid does not modulate the activity of P-gp/ABCB1 or MRP1/ABCC1 in a non-tumoral renal cell line: Possible utility in multidrug resistance cancer chemotherapy
}

\author{
JOÃO MARCOS DE AZEVEDO DELOU, MÁRCIA ALVES MARQUES CAPELLA and CERLI ROCHA GATTASS
}

\author{
Instituto de Biofísica Carlos Chagas Filho, CCS, Universidade Federal do \\ Rio de Janeiro, 21949-900 Rio de Janeiro, RJ, Brazil
}

Received September 26, 2008; Accepted November 20, 2008

\author{
DOI: $10.3892 / \mathrm{mmr} 00000095$
}

\begin{abstract}
Multidrug resistance (MDR) is a multifactorial phenomenon considered to be the main cause of failure in cancer chemotherapy. One of the underlying mechanisms of MDR is the overexpression of membrane transporter proteins, such as P-glycoprotein (P-gp/ABCB1) and multidrug resistance-associated protein 1 (MRP1/ABCC1). As these proteins are also expressed in normal tissues, considerable attention has been dedicated to the search for cytotoxic drugs that are not substrates for these proteins. This study investigated the effects of betulinic acid (BA) on the activity of ABCB1 and ABCC1 in Ma-104, a non-tumoral renal cell line constitutively expressing both proteins. The results indicated that concentrations of BA with low cytotoxicity to Ma-104 did not alter the activity of $\mathrm{ABCB} 1$ or $\mathrm{ABCC} 1$, nor did $\mathrm{BA}$ interfere with the accumulation of a classic chemotherapeutic, methotrexate. This suggests it would also be a good choice for use in drug cocktails. The lack of effect of BA on ABCB1 and $\mathrm{ABCC} 1$, as well as its antitumoral properties, suggest that this triterpene is a viable chemotherapeutic agent for MDR tumors.
\end{abstract}

\section{Introduction}

Multidrug resistance (MDR), the main cause of failure in cancer chemotherapy, is clinically defined as the crossresistance of tumor cells to several structurally and mechanistically different chemotherapeutic drugs. Although MDR may result from several mechanisms, such as defects in the regulation of apoptosis control genes, an increase in drug detoxification mechanisms and alterations in the DNA-repair systems, its predominant cause is the overexpression of membrane transporter proteins of the ATP binding cassette (ABC) superfamily. These proteins, namely P-glycoprotein (P-gp/ABCB1) (1), multidrug resistance-associated protein 1

Correspondence to: Dr Cerli Rocha Gattass, Laboratory of Cellular Immunology, Instituto de Biofísica Carlos Chagas Filho, CCS Bloco G, Universidade Federal do Rio de Janeiro, 21949-900 Rio de Janeiro, RJ, Brazil

E-mail: cerli@chagas.biof.ufrj.br

Key words: cancer, multidrug resistance, betulinic acid
(MRP1/ABCC1) (2) and breast cancer resistance protein (BCRP/ABCG2) (3) act as active pumps, decreasing cellular drug accumulation and toxicity.

The expression of MDR proteins has been correlated with poor patient prognosis in several types of tumors (4-7). In the last decade, considerable attention has been dedicated to the search for new strategies to overcome the mechanisms of drug resistance. Therapeutic approaches to bypassing MDR include the use of inhibitors or modulators of the pumps as adjuvants in chemotherapy. However, as MDR proteins are also expressed in normal tissues, where they exhibit physiological functions, the use of such substances is generally accompanied by undesirable side effects (8). Over the years, more selective and less toxic inhibitors of these transporters have been developed, but the clinical results have generally been disappointing $(9,10)$, indicating the need for new strategies. Among new approaches to the circumvention of MDR, one of the most promising is the use of drugs that are not substrates for transport, and that therefore do not lead to the undesirable side effects precipitated by the lack of function of the transporters.

Betulinic acid (BA), a triterpene of natural origin, was first described as an anti-neoplastic agent by Sheth et al in 1972 (11). Interest in this compound increased with the observation of its in vitro and in vivo activity against melanomas and tumors of neuro-ectodermal origin (12-14). Later, it was demonstrated that BA is also active in other types of tumors, including colon and prostate (15), lung, ovarian, cervical (16), leukemia (17), liver (18), and head and neck (19) carcinomas. Previous research by our group revealed that BA was cytotoxic to an MDR erythroleukemic cell line overexpressing P-glycoprotein, even in the absence of MDR modulators (20). This observation aroused interest in the further characterization of the cytotoxicity of this triterpene, particularly in non-tumoral cell lines.

Due to the growing interest in new compounds capable of overcoming the MDR phenotype for clinical praxis, the present study was performed to examine the effects of BA on the activity of $\mathrm{ABCB} 1$ and $\mathrm{ABCC} 1$ proteins in a non-tumoral renal cell line constitutively expressing both proteins (20). The results obtained indicate that BA had no effect on the activity or expression of these proteins in the cell line, and that it did not interact with a chemotherapic agent, methotrexate. This favors additional investigations directed towards the future use of BA in the treatment of MDR tumors. 


\section{Materials and methods}

Cells and culture conditions. The renal epithelial cell line Ma-104 (monkey kidney embryo) was grown in Dulbecco's modified Eagle's medium (DMEM) supplemented with $10 \%$ fetal bovine serum (Gibco, Grand Island, NY, USA) in disposable plastic bottles at $37^{\circ} \mathrm{C}$. Cells were sub-cultured using trypsin-EDTA every 3-4 days.

Analysis of cellular viability. Cells were seeded in 96-microwell plates at a concentration of $2 \times 10^{4}$ cells/well). Experiments were performed $24 \mathrm{~h}$ after seeding to ensure the uniform attachment of the cells at the onset of the experiments. Cells were then incubated for $48 \mathrm{~h}$ with BA concentrations varying from 1 to $100 \mu \mathrm{g} / \mathrm{ml}$. After incubation, cellular viability was measured by the thiazolyl blue tetrazolium (MTT) assay (21) on an ELISA reader (absorbance, $570 \mathrm{~nm}$; reference filter, $655 \mathrm{~nm}$ ). Each experiment was repeated at least three times using triplicate samples.

Intracellular accumulation of Rhodamine 123 and Fluo-3. Flow cytometry was used to measure intracellular fluorescence. Rhodamine 123 (Rho123, Sigma, USA) and Fluo-3 (Invitrogen, USA) were used for the measurement of ABCB1 and ABCC 1 activities, respectively $(21,22)$.

For each experiment, the cells were seeded in 24-well plates at a concentration of $1 \times 10^{5}$ cells $/ \mathrm{ml}(1 \mathrm{ml} /$ well $)$. After $24 \mathrm{~h}$, the cells were incubated for $30 \mathrm{~min}$ with $400 \mathrm{nM}$ Rho123 or $1 \mu \mathrm{M}$ Fluo-3 in the presence or absence of the desired $\mathrm{BA}$ concentrations. The classic $\mathrm{ABCB} 1$ and $\mathrm{ABCC} 1$ modulators cyclosporin A $(1 \mu \mathrm{M})$ and MK571 $(25 \mu \mathrm{M})$ were used as controls. The cells were then washed in PBS, harvested by trypsin-EDTA and kept on ice until evaluation by flow cytometry. Flow cytometry analysis was performed in a Becton-Dickinson cytometer (FACSCalibur) equipped with an air-cooled argon laser tuned to emit $15 \mathrm{~mW}$ at $488 \mathrm{~nm}$. Fluorescence was measured through a $530 \mathrm{~nm}$-long pass filter.

Western blot analysis. Expression of $\mathrm{ABCB} 1$ and $\mathrm{ABCC} 1$ was assessed by immunoblotting using specific antibodies (MRPm6 and JSB-1, respectively). Cells were plated onto 6-well plates, and BA $(10 \mu \mathrm{g} / \mathrm{ml})$ was added the next day. After $24 \mathrm{~h}$ of incubation, the culture medium was aspirated and the cells were washed three times with PBS ( $\mathrm{pH} 7.4)$ at room temperature, scraped, and centrifuged at $8,000 \mathrm{x} \mathrm{g}$ for $90 \mathrm{sec}$. Whole cell extracts were prepared and diluted in sample buffer consisting of $1.5 \%$ sodium dodecyl sulfate (SDS), $10 \mathrm{mM}$ Tris[hydroxymethyl]aminomethane (Tris-Cl), $\mathrm{pH} 6.8,0.6 \%$ dithio-L-threitol, $0.5 \%$ B-mercaptoethanol and $6 \%$ glycerol. The proteins were then subjected to SDSpolyacrylamide gel electrophoresis (PAGE) and transferred to a PVDF membrane (Bio-Rad, Hercules, CA, USA). The membranes were blocked with Western Breeze blocking solution (Invitrogen) and incubated with specific antibodies against ABCB1, ABCC1 or actin (Santa Cruz, USA). The phosphatase alkaline Western Breeze Kit (Invitrogen) was used to visualize the bands on the membranes.

Statistical analysis. Each experiment was repeated three to seven times. Data are expressed as the means \pm SEM and were analyzed by the paired one-tailed t-test (Figs. 2 and 4)

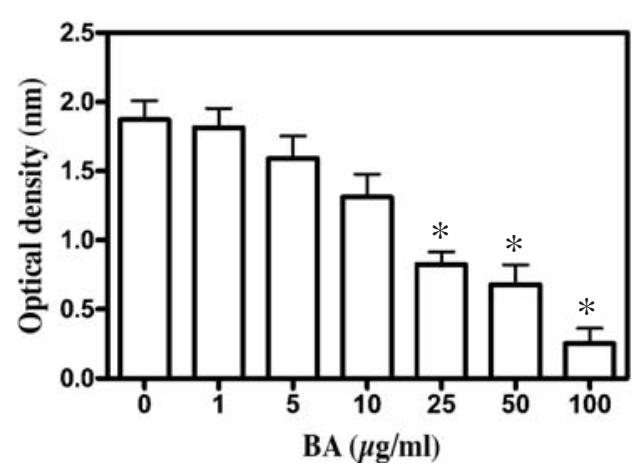

Figure 1. Effect of betulinic acid (BA) on Ma-104 cell viability. Cells were incubated with different BA concentrations for $48 \mathrm{~h}$. Cell viability was measured by MTT. Results are derived from seven experiments performed in triplicate. ${ }^{*} \mathrm{p}<0.001$ in relation to the control.

A

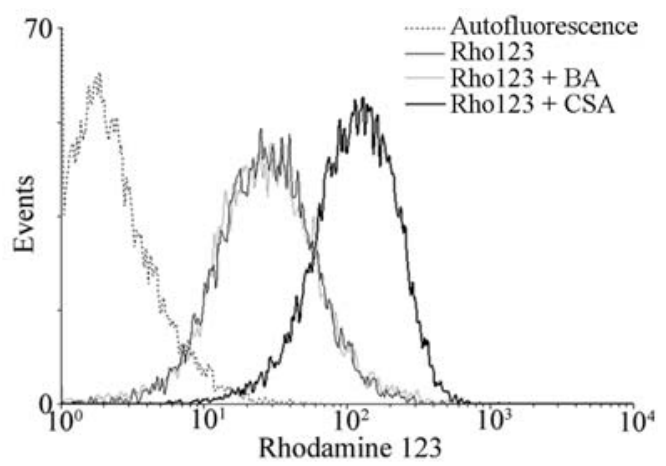

B

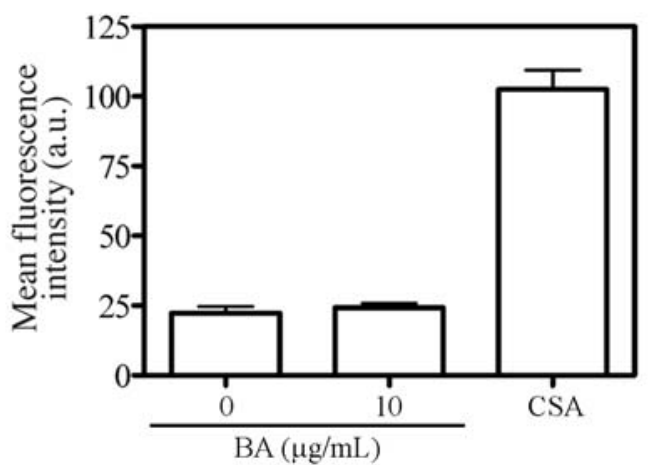

Figure 2. Effect of betulinic acid (BA) on Rhodamine 123 accumulation. Cells were incubated for $30 \mathrm{~min}$ with $400 \mathrm{nM}$ Rho123 in the presence or absence of $10 \mu \mathrm{g} / \mathrm{ml} \mathrm{BA}$. Cellular fluorescence was measured by flow cytometry. The accumulation of Rho123 in the presence of cyclosporin A was used as the control. (A) Representative histogram and (B) mean fluorescence intensity. Results are the mean of 3 experiments.

and one-way analysis of variance with Bonferroni's post test (Figs. 1 and 3). Values of $\mathrm{p}<0.05$ were considered statistically significant.

\section{Results}

The MTT assay was used to evaluate the effect of BA on Ma-104 cell viability. As shown in Fig. 1, BA decreased the viability of Ma-104 cells in a dose-dependent manner. High concentrations of BA were required to substantially decrease the viability of Ma-104 cells after 48 h of treatment; however, at $10 \mu \mathrm{g} / \mathrm{ml}$, a concentration at which BA is highly cytotoxic 
A

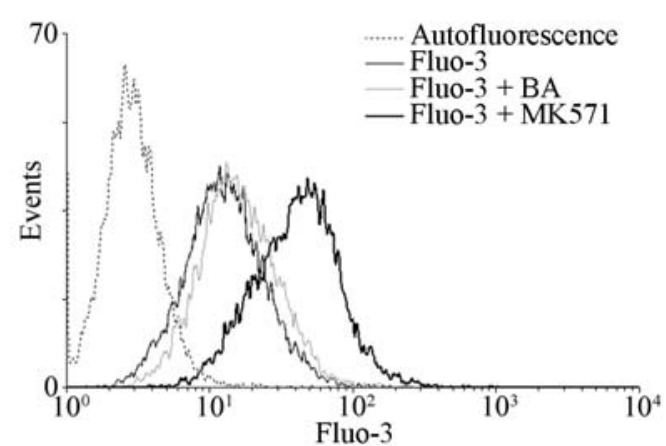

B

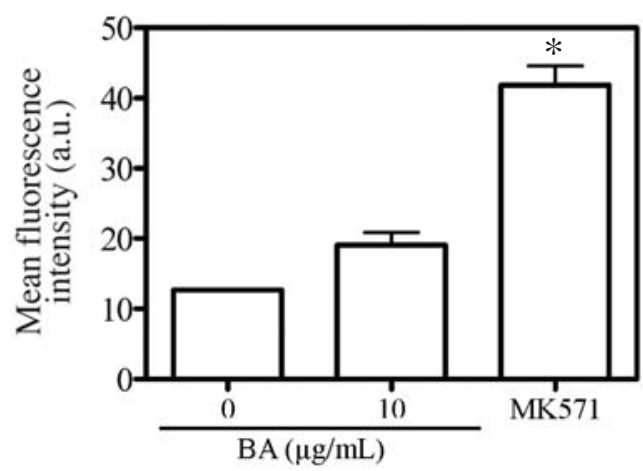

Figure 3. Lack of effect of betulinic acid (BA) on Fluo-3 accumulation. Cells were incubated for $30 \mathrm{~min}$ with $1 \mu \mathrm{M}$ Fluo-3 in the presence or absence of $10 \mu \mathrm{M}$ BA. Cellular fluorescence was measured by flow cytometry. Accumulation of Fluo-3 in the presence of MK571 $(25 \mu \mathrm{M})$ was used as the control (A) Representative histogram and (B) mean fluorescence intensity. ${ }^{*} \mathrm{p}<0.01$ in relation to the control.

to several tumor cell lines (14-19), the effect of BA on Ma-104 was very low. Thus, to avoid the possible interference of cell death mechanisms on the measurement of ABCB1 and $\mathrm{ABCC} 1$ activities, subsequent experiments were performed using $10 \mu \mathrm{g} / \mathrm{ml}$ of BA. At the incubation time used $(30 \mathrm{~min})$, this concentration had no effect on cell viability (results not shown).

We previously demonstrated that $\mathrm{BA}$ was cytotoxic to tumor cells overexpressing ABCB1 (24). However, there is no data regarding the effect of $\mathrm{BA}$ on $\mathrm{ABCB} 1$ and $\mathrm{ABCC} 1$ activity. To further analyze whether BA was able to inhibit $\mathrm{ABCB} 1$ or $\mathrm{ABCC} 1$ activity, Ma-104 cells were incubated for 30 min with Rho123 (ABCB1 substrate) or Fluo-3 (ABCC1 substrate) in the presence or absence of $\mathrm{BA}$, and the intracellular fluorescence was measured.

Fig. 2 shows that no significant alteration was noted in the fluorescence of cells incubated with $400 \mathrm{nM}$ Rho123 in the presence or absence of $\mathrm{BA}$, while a significant increase in fluorescence was observed in the presence of the $A B C B 1$ inhibitor cyclosporin $\mathrm{A}$, indicating that $\mathrm{BA}$ has no effect on $\mathrm{ABCB} 1$ activity. Moreover, no significant alteration was noted in the fluorescence of cells incubated with $1 \mu \mathrm{M}$ Fluo- 3 in the presence or absence of $\mathrm{BA}$, while a significant increase in fluorescence was observed in the presence of the classical ABCC1 inhibitor MK571, indicating that BA does not have an effect on $\mathrm{ABCC} 1$ activity either (Fig. 3).

The above results suggest that $\mathrm{BA}$ does not modulate $\mathrm{ABCB} 1$ or $\mathrm{ABCC} 1$ activity. However, flow cytometry experiments were performed for $30 \mathrm{~min}$, a time period which is too

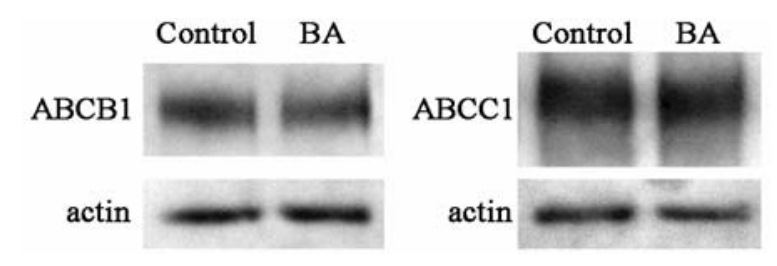

Figure 4. Betulinic acid (BA) does not alter $\mathrm{ABCB} 1$ or $\mathrm{ABCC} 1$ expression. Cells incubated with $10 \mu \mathrm{M}$ BA for $24 \mathrm{~h}$ were lysed and blotted against $\mathrm{ABCB} 1$ and $\mathrm{ABCC} 1$ antibodies. As a loading control, antibody against actin was used.
A

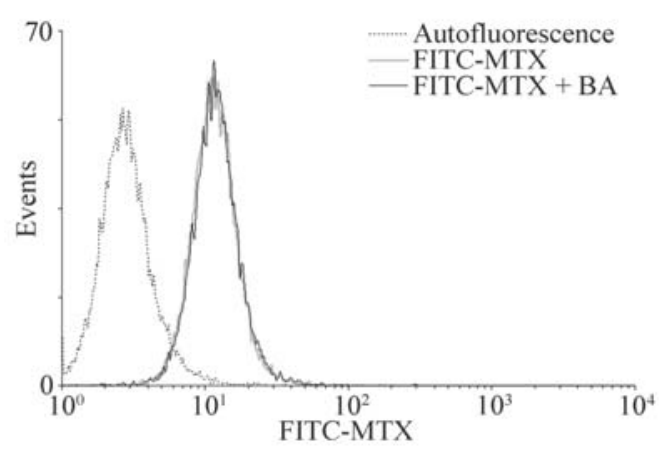

B

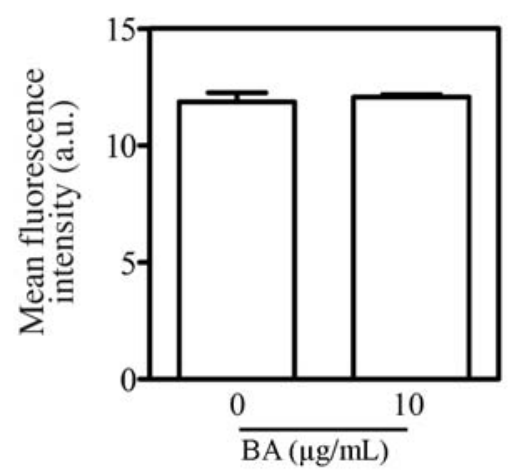

Figure 5. Betulinic acid does not affect methotrexate (MTX) accumulation. Cells were incubated for $30 \mathrm{~min}$ with $10 \mu \mathrm{M}$ FITC-MTX in the presence or absence of BA. Cellular fluorescence was measured by flow cytometry. (A) Representative histogram and (B) mean fluorescence intensity.

short for the observation of an alteration in protein expression. The remaining possibility that $\mathrm{BA}$ alters the expression of these proteins was therefore analyzed by immunoblotting. As shown in Fig. 4, BA did not alter the expression of ABCB1 or $\mathrm{ABCC} 1$ after $24 \mathrm{~h}$ of incubation, confirming that this triterpene has no effect on these proteins.

The fact that BA does not alter the expression or the activity of the two main proteins related to the MDR phenotype suggests that this triterpene does not alter the physiological functions of these transporters, nor the intracellular accumulation of the chemotherapeutics that are substrates for one (or both) proteins. Thus, BA could potentially be used in a chemotherapy cocktail without undesirable side effects, such as increased cytotoxicity. To test this hypothesis, we evaluated the intracellular accumulation of fluorescein methotrexate (FMTX) in the presence or absence of BA. As can be noted in Fig. 5, the results reveal that the intracellular accumulation of FMTX was indeed virtually the same in the presence or absence of BA. 


\section{Discussion}

Multidrug resistance remains a major problem facing cancer chemotherapy. The complexity and versatility of the cellular resistance mechanisms present in MDR tumors hamper clinical chemotherapy, favoring a bad prognosis for patients with this type of tumor. The mechanisms underlying the development of MDR are considered multifactorial. However, of these mechanisms, the drug efflux mediated by several ATP binding cassette transporters (in particular ABCB1 and ABCC1) is one of the best studied. Since several antineoplastic drugs are substrates for the MDR proteins, clinical approaches to circumvent MDR mechanisms have included the use of inhibitors or modulators of these pumps (10). Nevertheless, although many MDR inhibitors have been identified, none have proven to be without side effects (8). The expression of MDR proteins on normal tissues is probably the main factor of the observed side effects (25). Therefore, the identification of new anti-neoplastic drugs that can bypass resistance and do not modulate the activity or alter the expression of the two main MDR proteins is of great importance.

Our group is studying the anti-tumoral activity of several triterpenes of natural origin, and we have shown that several are cytotoxic for MDR cell lines (20,24,26-28). Additionally, the effect of oleanolic acid on the activity of MDR proteins has been investigated. Although it did not interfere with $\mathrm{ABCB} 1$ activity, oleanolic acid did modulate ABCC1 activity (20).

Betulinic acid is already known as a promising anticancer drug $(9,12,13,24)$, but its effects on MDR cells remain unclear. In a previous study, we demonstrated that BA was cytotoxic to an MDR erythroleukemia cell line that overexpresses ABCB1 (24). The antitumoral effect of BA was also observed in tumor cell lines with defective or mutated p53 $(13,16)$, as well as in cell lines that acquire resistance to cytotoxic drugs $(16,18)$. In this study, we investigated the effect of BA on Ma-104, a non-tumoral renal cell line that constitutively expresses P-gp/ABCB1 and MRP1/ABCC1 (20). The results show that, at lower concentrations $(\leq 10 \mu \mathrm{g} / \mathrm{ml})$, the cytotoxic effects of BA on Ma-104 cells are much smaller than those observed in tumor cell lines $(14,16,19,29)$, including those resistant to cytotoxic drugs $(16,30)$. Indeed, lack of BA activity at concentrations $\leq 20 \mu \mathrm{g} / \mathrm{ml}$ was reported in normal fibroblasts, peripheral blood lymphocytes, astrocytes and melanocytes $(13,16,17,31)$. The present study also showed that BA had no effect on the accumulation of Rho123 and Fluo-3 in this cell line, nor did it alter the expression of $\mathrm{ABCB} 1$ or $\mathrm{ABCC} 1$ in a long-term incubation, confirming the complete absence of the effects of BA on these proteins. Corroborating this hypothesis, BA had no effect on methotrexate accumulation, a chemotherapeutic known to be a substrate for ABCC1 (32).

One of the problems confronting the chemotherapy of MDR tumors is the expression of MDR proteins in normal tissues, leading to altered pharmacokinetics and increased toxicity, which hamper the clinical development of chemosensitizers (33). In view of this, it was postulated that an ideal chemotherapeutic should not be a modulator of MDR proteins (34). BA has already been suggested as a chemotherapeutic candidate, and the kidneys are organs related to drug biodisponibility. Thus, data in the literature demonstrating the antitumoral properties of BA in vitro and in vivo and the results presented herein, indicating that $\mathrm{BA}$ does not modulate $\mathrm{ABCB} 1$ and $\mathrm{ABCC} 1$ activity and/or expression in a renal cell line, suggest that this triterpene is a promising drug for the treatment of tumors refractory to the currently available therapeutic agents. Therefore, BA is a viable option for the chemotherapy of MDR tumors.

\section{Acknowledgements}

This work was supported by grants from Fundação Carlos Chagas Filho de Amparo à Pesquisa do Estado do Rio de Janeiro (FAPERJ), Programa de Oncobiologia (FAF/ONCO), Financiadora de Estudos e Projetos (FINEP/NQTN), Programa de Apoio aos Núcleos de Excelência (PRONEX) and Conselho Nacional de Desenvolvimento Científico e Tecnológico (CNPq), Brazil. João Marcos Delou was awarded a fellowship from $\mathrm{CNPq}$.

\section{References}

1. Juliano RL and Ling V: A surface glycoprotein modulating drug permeability in Chinese hamster ovary cell mutants. Biochim Biophys Acta 455: 152-162, 1976.

2. Cole SPC, Bhardwaj G, Gerlach JH, Malie J, Grant CE and Almquist KC: Overexpression of a transporter gene in a multidrugresistant lung cancer cell line. Science 258: 1650-1654, 1992.

3. Bates SE, Robey R, Miyake K, Rao K, Ross DD and Litman T: The role of halftransporters in multidrug resistance. J Bioenerg Biomemb 33: 503-511, 2001.

4. Mignogna C, Staibano S, Altieri V, De Rosa G, Pannone G, Santoro A, Zamparese R, D'Armiento M, Rocchetti R, Mezza E, Nasti M, Strazzullo V, Montanaro V, Mascolo M and Bufo P: Prognostic significance of multidrug-resistance protein (MDR-1) in renal clear cell carcinomas: a five-year follow-up analysis. BMC Cancer 6: 293-302, 2006.

5. Yeh JJ, Hsu NY, Hsu WH, Tsai CH, Lin CC and Liang JA: Comparison of chemotherapy response with P-glycoprotein, multidrug resistance-related protein-1, and lung resistance-related protein expression in untreated small cell lung cancer. Lung 183: 177-183, 2005.

6. Haber M, Smith J, Bordow SB, Flemming C, Cohn SL, London WB, Marshall GM and Norris MD: Association of high-level MRP1 expression with poor clinical outcome in a large prospective study of primary neuroblastoma. J Clin Oncol 24: 1546-1553, 2006.

7. Rioja Zuazu J, Bandrés Elizalde E, Rosell Costa D, Rincón Mayans A, Zudaire Bergera J, Gil Sanz MJ, Rioja Sanz LA, García Foncillas J and Berián Polo JM: Steroid and xenobiotic receptor (SXR), multidrug resistance gene (MDR1) and GSTs, SULTs and CYP polymorphism expression in invasive bladder cancer, analysis of their expression and correlation with other prognostic factors. Actas Urol Esp 31: 1107-1116, 2007.

8. Lee CH: Reversing agents for ATP-binding cassette (ABC) transporters: application in modulating multidrug resistance (MDR). Curr Med Chem Anticancer Agents 4: 43-52, 2004.

9. Liscovitch $M$ and Lavie $Y$ : Cancer multidrug resistance: A review of recent drug discovery research. IDrugs 5: 349-355, 2002.

10. Ozben T: Mechanisms and strategies to overcome multiple drug resistance in cancer. FEBS Lett 580: 2903-2909, 2006.

11. Sheth K, Jolad S, Wiedhopf R and Cole JR: Tumor-inhibitory agent from Hyptis emoryi (Labiatae). J Pharm Sci 61: 1819, 1972.

12. Pisha E, Chai H, Lee HS, Chagwedera TE, Farnsworth NR, Cordel GA, Beecher CW, Fong HH, Kinghorn AD and Brown DM: Discovery of betulinic acid as a selective inhibitor of human melanoma that functions by induction of apoptosis. Nat Med 1: 1046-1050, 1995.

13. Fulda S, Friesen C, Los M, Scaffidi C, Mier W, Benedict M, Nunez G, Krammer PH, Peter ME and Debatin KM: Betulinic acid triggers CD95 (APO-1/Fas)-and p53-independent apoptosis via activation of caspases in neuroectodermal tumors. Cancer Res 57: 4956-4964, 1997. 
14. Tan YM, Yu R and Pezzuto JM: Betulinic acid-induced programmed cell death in human melanoma cells involves mitogen-activated protein kinase activation. Clin Cancer Res 9: 2866-2875, 2003

15. Kim JY, Koo HM and Kim DS: Development of C-20 modified betulinic acid derivatives as antitumor agents. Bioorg Med Chem Lett 11: 2405-2408. 2001.

16. Zuco V, Supino R, Righetti SC, Cleris L, Marchesi E, GambacortiPasserini C and Formelli F: Selective cytotoxicity of betulinic acid on tumor cell lines, but not on normal cells. Cancer Lett 175: 17-25, 2002.

17. Ehrhardt H, Fulda S, Fuhrer M, Debatin KM and Jeremias I: Betulinic acid-induced apoptosis in leukemia cells. Leukemia 18: 1406-1412, 2004.

18. Sarek J, Klinot J, Dzubak P, Klinotova E, Noskova V, Krecek V, Korinkova G, Thomson JO, Janost'akova A, Wang S, Parsons S, Fischer PM, Zhelev NZ and Hajduch M: New lupane derived compounds with pro-apoptotic activity in cancer cells: synthesis and structure-activity relationships. J Med Chem 46: 5402-5415, 2003.

19. Thurnher D, Turhani D, Pelzmann M, Wannemacher B, Knerer B Formanek M, Wacheck V and Selzer E: Betulinic acid: a new cytotoxic compound against malignant head and neck cancer cells. Head Neck 25: 732-740, 2003.

20. Braga F, Ayres-Saraiva D, Gattass CR and Capella MAM: Oleanolic acid inhibits the activity of the multidrug resistance protein ABCC1 (MRP1) but not of the ABCB1 (P-glycoprotein): possible use in cancer chemotherapy. Cancer Lett 248: 147-152, 2007.

21. Mosmann T: Rapid colorimetric assay for cellular growth and survival: application to proliferation and cytotoxicity assays. J Immunol Methods 65: 55-63, 1983

22. Neyfakh AA: Use of fluorescent dyes as molecular probes for the study of multidrug resistance. Exp Cell Res 174: 168-176, 1988.

23. Keppler D, Cui Y, König J, Leier I and Nies A: Export pumps for anionic conjugates encoded by MRP genes. Adv Enzyme Regul 39: 237-246, 1999.

24. Fernandes J, Castilho RO, Da Costa MR, Wagner-Souza K, Kaplan MAC and Gattass VR: Pentacyclic triterpenes from Chrysobalanaceae species: cytotoxicity on multidrug resistant and sensitive leukemia cell lines. C ancer Lett 190: 165-169, 2003.
25. Leslie EM, Deeley RG and Cole SPC: Multidrug resistance proteins: role of P-glycoprotein, MRP1, MRP2 and BCRP (ABCG2) in tissue defense. Toxicol Appl Pharmacol 204: 216-237, 2005.

26. Fernandes F, Weinlich R, Castilho RO, Amarante-Mendes JGP and Gattass CR: Pomolic acid may overcome multidrug resistance mediated by overexpression of anti-apoptotic Bcl-2 proteins. Cancer Lett 245: 315-320, 2007.

27. Rocha GG, Simões M, Lúcio KA, Oliveira RR, Kaplan MAC and Gattass CR: Natural triterpenoids from Cecropia lyratiloba are cytotoxic to both sensitive and multidrug resistant leukemia cell lines. Bioorg Med Chem 15: 7355-7360, 2007.

28. Vasconcelos FC, Gattass CR, Rumjanek VM and Maia RC: Pomolic acid-induced apoptosis in cells from patients with chronic myeloid leukemia exhibiting different drug resistance profile. Invest New Drugs 25: 525-533, 2007.

29. Jeremias J, Steiner HH, Benner A, Debatin K-M and HeroldMende C: Cell death induction by betulinic acid, ceramide and TRAIL in primary glioblastoma multiforme cells. Acta Neurochir 246: 721-729, 2004.

30. You YJ, Kim K, Nam NH and Ahn BZ: Synthesis and cytotoxic activity of A-ring modified betulinic acid derivatives. Bioorg Med Chem Lett 13: 3137-3140, 2003

31. Wick W, Grimmel C, Wagenknecht B, Dichgans J and Weller M: Betulinic acid-induced apoptosis in glioma cells: a sequential requirement for new protein synthesis, formation of reactive oxygen species, and caspase processing. J Pharmacol Exp Ther 289: 1306-1312, 1999.

32. Hooijberg JH, Broxterman HJ, Kool M, Assaraf YG, Peters GJ, Noordhuis P, Scheper RJ, Borst P, Pinedo HM and Jansen G: Antifolate resistance mediated by the multidrug resistance proteins MRP1 and MRP2. Cancer Res 59: 2532-2535, 1999

33. Kerb R: Implications of genetic polymorphisms in drug transporters for pharmacotherapy. Cancer Lett 234: 4-33, 2006.

34. Robert $\mathrm{J}$ and Jarry $\mathrm{C}$ : Multidrug resistance reversal agents. $\mathrm{J}$ Med Chem 46: 4805-4817, 2003. 